\title{
MITRA-MITHRA-MITHRAS: THE ROMAN MITHRAS AND HIS INDO-IRANIAN BACKGROUND
}

\begin{abstract}
Summary: One of the key questions in the studies of the Roman cult of Mithras has been, since the works of F. Cumont, the question about the religious historical origin of the cult - regarding which there is no consensus to this day. Theories about the origin of the cult can be divided into three groups: (1) the so-called "strong" Iranian thesis, according to which the cult was imported from Iran; (2) the so-called "weak" Iranian thesis, claiming that just a few, mostly irrelevant elements of the cult originated in Iran; (3) a radical stance that there is no consistency between the Roman cult of Mithras and the Iranian cult of Mithra and what the two have in common is simply the similar name of a god. The author of this presentation has studied comparatively the character of Mitra in Indian religious literature, that of Mithra in Iranian religious and mythological texts as well as in Iranian religious iconography, and Mithras in the cult devoted to him in Rome, and has concluded that the radical belief common in current Mithras studies, according to which Mithras is connected with Mitra and Mithra only by them having similar names, is just as erroneous as the "strong" Iranian thesis defended by F. Cumont and G. Widengren. Although it is certain that the Roman cult of Mithras is not a cult imported from Iran, but a new cult that originated in the Roman Empire, the author of this presentation maintains that the Roman cult of Mithras contains a series of motifs that can be found both in the Vedas and in Iranian mythological texts: connection of Mitra/Mithras with friendship and a contract of friendship; certain military traits; connection with cosmogony and the cosmic order; connection with light, the Sun and the chariot of Sol; the role of the god as a giver of water and fertility; the idea of a sacrifice that stimulates fertility. Based on the sources linked to the Roman Mithras, in particular the iconography, it may be claimed that a large part of these motifs did not have a peripheral role in the mythology connected with the cult, but they carried an important, maybe even a central role. As the previously mentioned motifs were already interrelated in India and Iran, the author of this presentation believes that their coexistence in the mythology of the Roman cult of Mithras cannot be a coincidence but testifies to the wider Indo-Iranian background of the central figure of the cult, the god Mithras, which should not be ignored even if the Roman cult of Mithras is viewed as a new cult that evolved in the Roman Empire and within the context of the Greco-Roman religion.
\end{abstract}

Key words: Mitra, Mithra, Mithras, Iran, India, Asia Minor, Indo-Iranian mythology, coins of the Kushan Empire, rock relief in Tāq-e Bostān, Mithras picture in Bāmīan, Avesta, Yašt 10, Bundahišn 


\section{INTRODUCTION}

The ninth book of the Odyssey is about the Cyclopes who live in isolation from the outside world on the their island. They do not have a city or a state, they are not familiar with farming and - the main thing - they do not visit foreign lands because they do not have any ships. ${ }^{1}$ The Swiss scholar Walter Burkert says that for a long time European scholars considered the ancient Greeks to be similar to those Cyclopes. ${ }^{2}$ Greek culture was seen as an independent phenomenon that appeared without considerable influences from other cultures. Burkert claims that today this point of view has been abandoned, because, due to studies of ancient oriental history, literature and mythology, it has become obvious how much the Greek civilization has been influenced by other ancient Mediterranean civilizations, influences can be and these are shown in such fields as language, literature and mythology, as Burkert has argued. ${ }^{3} \mathrm{He}$ claims that the study of Mediterranean cultural space as a whole has now the normal practice.

One extreme was to study cultures in isolation and deny any intercultural communication or mutual influences. The other extreme is the concept of the diffusionism, according to which every cultural phenomenon initially occurred only once, in one place, and then spread from there to everywhere else. At the end of the 19th century this point of view was dominant in cultural studies, and because of that all kinds of "pantheories" were popular; undoubtedly the most influential theory was panbabylonism. In the last decades of the 19th century, when among scholars the interest in so-called "oriental cults" in the late Roman Republic and Empire emerged, the appearance of new cults in the Roman State was also explained with the help of the diffusion model. ${ }^{4}$ Thus Franz Cumont interpreted the Roman cult of Mithras as an Iranian cult that was imported into the Roman State and then began to spread there. ${ }^{5}$ The impact of Cumont was so great that only in the 1970s did his point of view begin to be considered erroneous. ${ }^{6}$ The idea that the cult of Mithras emerged in the Roman State without any direct influences from the Orient had become the norm. According to this, the cult of Mithras should primarily be seen in the context of Greco-Roman

${ }^{1}$ Hom. Od. 9. 125-129.

2 BURKERT, W.: Die Griechen und der Orient. München 2009, 9.

${ }^{3}$ BURKERT: Die Griechen (n. 2); BURKERT, W.: Die orientalisierende Epoche in der griechischen Religion und Literatur. [Sitzungsberichte der Heidelberger Akademie der Wissenschaften, Philosophischhistorische Klasse 1]. Heidelberg 1984; BURKERT, W.: The Orientalizing Revolution: Near Eastern Influence on Greek Culture in the Early Archaic Age. Cambridge, MA 1992; BURKERT, W.: Babylon, Memphis, Persepolis: Eastern Contexts of Greek Culture. Cambridge, MA 2004.

${ }^{4}$ See LAHE, J.: Die orientalischen Religionen im Römerreich als ein Problem der Religionsgeschichte. Zeitschrift für Religionswissenschaft 20.2 (2012) 151-195, here 156-179.

${ }^{5}$ CUMONT, F.: Die orientalischen Religionen im römischen Heidentum. 4. unveränderte Aufl. Darmstadt 1969, 177.

${ }^{6}$ BECK, R.: Mithraism since Franz Cumont. ANRW II.17.4. Berlin 1984, 2002-2115, esp. n. 83; GORDON, R.: Von Cumont bis Clauss. Ein Jahrhundert Mithras-Forschung. In Imperium der Götter. Isis, Mithras, Christus. Kulte und Religionen im römschen Reich. Karlsruhe 2013, 237-242; LAHE, J.: Hat der römische Mithras-Kult etwas mit dem Iran zu tun? Überlegungen zu Beziehungen zwischen dem römischen Mithras-Kult und der iranischen religiösen Überlieferung. Usuteaduslik Ajakiri 67.2 (2014) 78110, here 79-87. 
religion, particularly in the context of the mystery cults; ${ }^{7}$ one can say that now this point of view has become prevalent. ${ }^{8}$ But there are scholars who have gone to the other extreme and claim that Roman Mithras differs radically from the Iranian Mith$\mathrm{ra}$, and that there is no connection between those two cults - neither in details nor as in a whole. ${ }^{9}$ As far as I am concerned, supporters of this point of view see the founders of the cult of Mithras in the same way as 19th century researchers viewed the Cyclopes as the same as the ancient Greeks, as Burkert explained. Yet, we know very well that the Romans did not live in isolation. In addition to contacts with Greek culture that were formed already when the first Greek colonies were established in Italy, in the period of Republic there were tight contacts between Romans and peoples who lived in the eastern part of Mediterranean region, who had founded the most ancient civilizations of the Ancient East and whose territories were gradually joined to the Roman State.

Moreover, one must not forget that the Roman State, during the period of the Roman Empire, had very tight relations with several distant cultures that were established in the east to the Roman State. Parthia, later Persia, was Rome's nearest neighbor, and Persian culture had been profoundly influenced by the Greeks in Asia Minor already before the territory was joined to the Roman State. ${ }^{10}$ Since the end of the Republic, Rome had had tight trade contacts with India, from where precious stones and other luxury goods were brought and with whom, especially during the 1st and 2nd centuries CE, Rome had regular contacts. ${ }^{11}$ Several Indian states sent their embassies to Rome. Indian ambassadors visited Rome during the reign of emperors Trajan, Hadrian, Antoninus Pius, Elagabalus, Aurelian and Constans. Roman merchants settled in India, especially in the region of Madurai. The ruins of a Roman city have been discovered on Coromandel coast near to Pondicherry that is located in the south-eastern part of India. ${ }^{12}$ Rome had also close contacts with the Kushan Empire that was situated in Central Asia; its monetary system was created on the example of Roman models and most likely with

${ }^{7}$ See Vermaseren, M. J.: Corpus Inscriptionum et Monumentorum Religionis Mithriacae. Vol. II [CIMRM II]. The Hague 1960, 1020; MERKELBACH, R.: Mithras. Ein persisch-römischer Mysterienkult. 2. Aufl. Weinheim 1994, 75-76; Clauss, M.: Mithras. Kult und Mysterium. Darmstadt 2012, 23-24; BURKERT, W.: Antike Mysterien. Funktionen und Gehalt. München 1990, 9-18; GORDON, R.: Mithras. In Der Neue Pauly 8 (2000) 287-292, here 287-288.

${ }^{8}$ See Witschel, CHR.: Die Ursprünge des Mithras-Kults. Orientalischer Gott oder westliche Neuschöpfung? In Imperium der Götter. Isis, Mithras, Christus. Kulte und Religionen im römschen Reich. Karlsruhe 2013, 201-210; BECK, R.: Mithraism after Mithraism since Franz Cumont 1984-2003. In BECK, R.: Beck on Mithraism. Collected Works with New Essays. Aldershot 2004, 3-30.

${ }^{9}$ Clauss (n. 7) 8 and 17; Hensen, A.: Mithras. Der Mysterienkult an Limes, Rhein und Donau [Schriften des Limesmuseums Aalen 62]. Stuttgart 2013, 24.

${ }^{10}$ See about that BURKERT: Die Griechen (n. 2) 107-133.

${ }^{11}$ DiHLE, A.: Die entdeckungsgeschichtlichen Voraussetzungen des Indienhandels der römischen Kaiserzeit. In DiHlE, A.: Antike und Orient. Gesammelte Aufsätze. [Supplemente zu den Sitzungsberichten der Heidelberger Akademie der Wissenshaften. Philosophisch-historische Klasse 2]. Heidelberg 1984, 118-152; see also DANIELOU, A.: India ajalugu [A Brief History of India]. Trans. by M. Kalda. Tallinn 2011, 132-134.

${ }^{12}$ Danielou (n. 11) 133. 
the help of Romans. ${ }^{13}$ As it has been shown by Paul Veyne ${ }^{14}$ and Alain Danielou, ${ }^{15}$ the Romans had relations with even more distant regions of Asia, including Indonesia. The colony of Roman mercenaries existed in Gansu, the most western province of China, already in the 1 st century BC. ${ }^{16}$ On the other hand, in Rome itself and in other Italian cities there lived people with very different ethnic and cultural origins. ${ }^{17}$ Through these contacts not only were goods spread, but ideas as well, although the ways of spreading ideas cannot usually be shown as literally as the distribution of goods. However, perhaps it is not a coincidence that the earliest information about Buddha and the Buddhism comes from Clement of Alexandria. ${ }^{18}$ Alexandria was, after all, one of the most important port cities through which the interaction with India took place. Dion Chrysostom claims that during his lifetime (i.e. in 2nd century AD), there was a permanent Indian colony in Alexandria. ${ }^{19}$ Manichaeism, that appeared in the Sassanid Empire, crossed the borders of the Roman Empire already in the 3rd century AD, so that the emperor Diocletian had to issue the edict to prevent the spread of that religion. ${ }^{20}$ And one must also not forget that in the Roman Empire an approach to the ancient wisdom possessed by Oriental peoples - Egyptians, people of Mesopotamia, Persians and Indians - was popular. Romans inherited this practice from the Greeks, who admired and respected oriental high cultures very much as early as the time of Plato. ${ }^{21}$ As it has been demonstrated by Jörg Rüpke and several other contemporary scholars, this kind of image of the Orient had strong impact on the 19th and 20th century scholars' studies in "oriental religions" in the Roman State. 22 But let us return to the topic of Mithras.

${ }^{13}$ MaCDOWALl, D. W: The Role of Mithra among the Deities of the Kusana Coinage. In HiNNELls, J. R. (ed.): Mithraic Studies. Proceedings of the First International Congress of Mithraic Studies. Manchester 1975, I 142-150; MACDowALL, D.: Mithra's Planetary Setting in the Coinage of the Great Kushans. In Duchesne-Guillemin, J. (ed.): Études Mithriaques. Actes du $2^{e}$ Congrès International Téhéran, du ler au 8 septembre 1975 [Acta Iranica 17]. Teheran-Liège 1978, 305-316, here 305-311.

${ }^{14}$ VEYNE, P.: Humanitas: roomlased ja teised [Humanitas: Romans and Non-Romans]. In GiardinA, A. (ed.): Vana-rooma inimene (L'uomo romano). Trans. by K. Ezzoubi. Tallinn 2004, 365395 , here 369 .

${ }^{15}$ DANIELOU (n. 11) 132.

${ }^{16}$ ADSHEAD, S. A. M: China in World History. 2nd ed. New York 1995, 34.

${ }^{17}$ NOY, D.: Foreigners at Rome. Citizens and Strangers. London 2000, $205 \mathrm{ff}$.

${ }^{18}$ Strom. I 15.

${ }^{19}$ DANIELOU (n. 11) 133.

${ }^{20}$ LIEU, S.: Manichaeism in the Later Roman Empire and Medieval China [WUNT 63]. Tübingen 1992, 120-125; SESTON, W.: Echtheit und Datierung des diokletainischen Edikts gegen die Manichäer. In WidENGREN, G. (Hrsg.): Der Manichäismus [Wege der Forschung 168]. Darmstadt 1977, 374-384.

${ }^{21}$ DiHLE, A.: Die Griechen und die Fremden. München 1994, 105-121.

${ }^{22}$ See about that BONNET, C. - RÜPKE, J.: Einleitung. In BONNET, C. - RÜPKE, J. (eds): Les 'religions orientales' dans le monde grec et romain [Trivium 4]. Paris 2009, http://trivium. Revues.org/3516; AUFFARTH, CHR.: Zwischen Anpassung und Exotik. „Mysterien“ und „Orientalische Kulte“ in der Religion der Antike. Verkündigung und Forschung 2 (2007) 19-30; AUFFARTH, CHR.: Religio migrans: Die „Orientalischen Religionen“ im Kontext antiker Religion. Ein theoretisches Modell. Mediterranea 4 (2007b) 333-363; BONNET, C.: Die „Orientalischen Religionen“ im Laboratorium des Hellenismus: Franz Cumont. Trivium. Revue franco-allemande de sciences humaines et sociales - revues.org/index $3452 . \mathrm{html}$. Frz. - Mediterranea. Deutsch-französische Zeitschrift für Geistes- und Sozialwissenschaften 4 (2009) http:/trivium; LAHE: Die orientalischen Religionen (n. 4) 151-195. See also WITSCHEL, CHR.: Orientali- 


\section{THE IRANIAN MITHRA AND ROMAN MITHRAS}

The opinion that the Roman cult of Mithras has grown out of the Iranian cult of Mithra nowadays does not have any supporters, and rightly so, because there are too many elements in that cult that do not have any relations with Iran. However, it does not mean that the cult (or to be more exact its deity) would not have any kind of connections with Iran. By "Iran" I do not mean strictly an historical Persian territory, but the whole Iranian cultural space, stretching from Armenia to Central Asia, and its sphere of influence belonged also to a part of Asia Minor after the Achaemenids' conquests. ${ }^{23}$ In Asia Minor the cult of Mithra has been proven already in the preChristian Era $^{24}$ and many scholars suppose that Mithras was introduced to Romans from Asia Minor. ${ }^{25}$ This concerns, however, only Mithras as a mythological figure and some of his iconographic attributes, ${ }^{26}$ not the cult of mystery that was created around him, since its existence can not be proven before the imperial era.

The main points of contact between the Iranian Mithra and the Roman Mithras are as follows:

1) The historical tradition. There is an historical tradition proven by different ancient authors that relates Mithras worshipped in Rome to the Iranian Mithra. This tradition is represented by Statius, ${ }^{27}$ Lucian, ${ }^{28}$ Porphyry ${ }^{29}$ and many other authors of the imperial era. Of course this tradition does not give any information about the real origin of the Roman cult of Mithras, but it proves that at the time this cult was spreading in the Roman State, it was considered to be an Iranian cult and the cult followers

sche Kulte im römischen Reich - neue Perspektiven der altertumswissenschaftlichen Forschung. In BLÖMER, M. - WINTER, E. (Hrsg.): Iuppiter Dolichenus [Orientalische Religionen in der Antike 8]. Tübingen 2012, 13-38.

${ }^{23}$ See SChwertheim, E.: Kleinasien in der Antike. Von den Hethitern bis Konstantin. München 2005, 43-54; MAREK, CHR.: Geschichte Kleinasiens in der Antike. 2. Aufl. München 2010, 204-227.

${ }^{24}$ See LAHE, J.: Mithra in Kleinasien und Mithra(s) im Römerreich: Sind die römische MithrasMysterien in Kleinasien entstanden? In ESPAK, P. - LÄÄNEMETS, M. - SAZONOV, V. (eds): Studia in Honorem Tarmo Kulmar. When Gods Spoke. Researches and Reflections on Religious Phenomena and Artefacts [Studia Orientalia Tartuensia. Series Nova VI]. Tartu 2015, 185-196, here 185-188.

${ }^{25}$ Vermaseren, M. J.: Mithras. Geschichte eines Kultes. Stuttgart 1965, 9, 21-22; WIDENGREN, G.: Die Religionen Irans [Die Religionen der Menschheit 14]. Stuttgart 1965, 224; SCHMEJA, H.: Iranisches und Griechisches in den Mithrasmysterien [Innsbrucker Beiträge zur Sprachwissenschaft. Vorträge 13]. Innsbruck 1975, 11; UlANSEY, D.: Die Ursprünge des Mithraskults. Kosmologie und Erlösung in der Antike. Darmstadt 1989; Schwertheim (n. 23) 97-100; MEYER, E.: Geschichte des Altertums. Bd. 3. Stuttgart 1954, 75; BECK, R.: The Mysteries of Mithras: A New Account of Their Genesis. Journal of Roman Studies 88 (1998) 115-128; BECK, R.: The Religion of the Mithras Cult in the Roman Empire: Mysteries of the Unconquered Sun. Oxford 2006; GORDON, R.: Mithras (Mithraskult). In Reallexikon für Antike und Christentum 24 (2012) 964-1009, 964; GORDON, R.: From Mithra to Roman Mithras. In StAuSBERG, M. - SOHRAB-DinShAw VeVAinA, Y. (ed.): The Wiley Blackwell Companion to Zoroastrianism. Wiley Blackwell 2015, 451-455.

${ }^{26}$ See about those LAHE: Mithra in Kleinasien (n. 24) 188-189.

${ }^{27}$ Thebais I 716-720.

${ }^{28}$ Deor. conc. 9.

${ }^{29}$ De antro nympharum 6. 
probably shared the same opinion. ${ }^{30}$ Similarities between the Roman cult of Mithras and the Iranian one have been proven by various details, ${ }^{31}$ such as the depiction of Mithras in Iranian style clothing, the name of degree of initiation perses ("Persian"), the cult greeting nama, ${ }^{32}$ or the title Nabarzes. ${ }^{33}$ The fact that Mithras is "the god of the Persians" was known to Greek readers already in antiquity due to Herodotus ${ }^{34}$ and Xenophon. ${ }^{35}$

2) The Gods' names (I deliberately use the word "names", since I do not identify the Iranian Mithra with the Roman Mithras). It is a fact that the name "Mithras" is a Latinized form of the name Mithra. At the moment I will not explain different ways of translating the name of the Iranian god Mithra. ${ }^{36}$ I will just mention that I prefer - instead of the traditional translation of his name as "treaty" - the equivalent "treaty of friendship", as suggested by Paul Thieme. "The God's name "Mitra" also occurs in India, and there it is usually translated as "friend", but I prefer once again Paul Thieme's translation "friend through a treaty". ${ }^{38}$ In some contexts the Iranian Mithra can be translated also as "alliance". In the mythology of Roman cult of Mithras, an important motive is creating an alliance or a treaty of friendship between Mithras and sun god Helios/Sol, as is depicted in numerous reliefs. The alliance or treaty of friendship is expressed by reaching out a hand to another; according to Manfred Clauss it was not a common greeting in Rome, but a special gesture that was related to creating an alliance of friendship. ${ }^{39}$ On one of the reliefs found in Poetovio (Ptuj), Mithras and sun god are reaching their hands to each other above the altar on which the fire burns. Both their hands are holding the spit of meat. ${ }^{40}$ Joint meals have always

${ }^{30}$ Alvar, J.: Romanising Oriental Gods: Myth, Salvation and Ethics in the Cults of Cybele, Isis and Mithras. Leiden-Boston 2008, 101.

${ }^{31}$ See about all those LAHE: Hat der römische Mithras-Kult etwas mit dem Iran zu tun? (n. 6) $88-103$.

32 Vermaseren, M. J.: Corpus Inscriptionum et Monumentorum Religionis Mithriacae. Vol. I [CIMRM I]. The Hague 1956, 54, 56-62, 416, 480-482, 484; CIMRM II 63 a and b. About that, see WIDENGREN: Die Religionen (n. 25) 225; ClAUSS (n. 7) 144; SCHMEJA (n. 25) 18.

${ }^{33}$ CIMRM I 915, 1790; CIMRM II 2153, 2197. About that, see WIDENGREN: Die Religionen (n. 25) 225; SCHMEJA (n. 25) 17-18; GORDON: From Mithra (n. 25).

${ }^{34}$ See Hist. I 131.

${ }^{35}$ Cyroupaid. VI 5. 53; Oeconom. IV 24.

${ }^{36}$ About them and the etymology of the name, see BAILEY, H. W.: The second stratum of the Indo-Iranian gods. In HinNells, J. R. (ed.): Mithraic Studies. Proceedings of the First International Congress of Mithraic Studies. Manchester 1975, I 1-20, here 15-16; THIEME, P.: The Concept of Mitra in Aryan belief. In Hinnells, J. R. (ed.): Mithraic Studies. Proceedings of the First International Congress of Mithraic Studies. Manchester 1975, I 21-33, here 25-33; SCHMIDT, H.-P.: Indo-Iranian Mitra Studies: The State of the Cental Problem. In DucheSne-Guillemin (n. 13) 345-394; PuHVEL, J.: Mithra as an Indo-European Divinity. In Duchesne-Guillemin (n. 13) 335-343; Bonfante, G.: The Name of Mithra. In DuCHESNE-GuILlEMIN (n. 13) 47-57; MAYERHOFER, M.: Die bisher vorgeschlagenen Etymologien und die ältesten Bezeugungen des Mithra-Namens. In DUCHESNE-GUILLEMIN (n. 13) 317-325.

37 Thieme, P.: Mitra and Aryaman. New Haven, CT 1957; THIEME, P.: Mithra in the Avesta. In DUCHESNE-GUILLEMIN (n. 13) 501-510.

38 THIEME: The Concept (n. 36) 25-33.

${ }^{39}$ CLAUSS (n. 7) 144.

${ }^{40}$ CIMRM II 403 - Mon. 1584. See ClAuSS (n. 7) 144, photo 20, and MERKELBACH (n. 7) Abb. 138. 
been a part of creating unions and treaties. ${ }^{41}$ It is probably not a coincidence that the followers of the cult of Mithras called themselves syndexioi - "those who are related through a handshake". ${ }^{42}$ Many images of shared meals by the sun god and Mithras can mark a meal celebrating the creation of friendship. As an iconographic parallel to the handshake one can mention images from the late Hellenism from Asia Minor that represent the local king of Kommagene, Antiochus I, shaking hands with various gods, with Mithra among them. ${ }^{43}$ On these reliefs, similarly to Roman ones, we do not see a human and a god shaking hands, but two gods, since it is known that king Antiochus was a god-king. 44

3) The solar nature of gods. Although in the Avesta the sun and Mithra have not yet been equated (and several authors of antiquity assure that in the Achaemenid period they were considered separate deities ${ }^{45}$ ), one can already see a tight connection between Mithra and the sun in the Avesta. Mithra drives a chariot pulled by white horses and it has one golden wheel. ${ }^{46}$ It is obvious that this is a chariot of the sun that is represented also in Greek mythology. The beginning of the identification of Mithra and the sun took place in Iranian cultural space during the Parthian (Arsacid) era. Since then, the word mihr came to mean also "the sun"47 and Mithra was depicted with the corona around his head. In this way we see him on images from the late Hellenistic period from Asia Minor, ${ }^{48}$ on the coins of the Kushan Empire from the 1st and 2 nd centuries $\mathrm{AD},{ }^{49}$ as well as on the monuments from the Sassanids' era: on one of the seals, ${ }^{50}$ on the coins of king Ohrmizd I, ${ }^{51}$ and also on the rock relief in Tâq-e Bostān. ${ }^{52}$ Mithra, driving a chariot of the sun with white horses, was depicted in one

${ }^{41}$ Merkelbach (n. 7) 5-6.

${ }^{42}$ See Clauss (n. 7) 101.

${ }^{43}$ See about them MAREK (n. 23) 633-636; JACOBS, B.: Das Heiligtum auf dem Nemrud Dagi. Zur Baupolitik des Antiochos I. von Kommagene und seines Sohnes Mithridates II. In WAGNER, J. (Hrsg.): Gottkönige am Euphrat. Neue Ausgrabungen und Forschungen in Kommagene. Mainz 2012, $77-$ 87; LAHE: Mithra in Kleinasien (n. 24) 187-189.

${ }^{44}$ See about that WAGNER, J.: Die Könige von Kommagene und ihr Herrscherkult. In WAGNER, J. (Hrsg.): Gottkönige am Eufrat. Neue Ausgrabungen und Forschungen in Kommagene. Darmstadt-Mainz 2012, 43-60.

${ }^{45}$ See Herod. Hist. I 231; Curtius Rufus, Hist. Alex. IV 13. 12.

${ }^{46}$ Yašt 10. 13.

${ }^{47}$ FrYe, R. N.: Mithra in Iranian History. In Hinnells, J. R. (ed.): Mithraic Studies. Proceedings of the First International Congress of Mithraic Studies. Manchester 1975, I 62-67, here 66.

${ }^{48}$ See JACOBS (n. 43) 77-87; see also CIMRM I 32 II A and WALDMANN, H.: Der Kommagenische Mazdaismus. Tübingen 1991, 204-207.

${ }^{49}$ See MACDOwALL: The role (n. 13) 142-150; MACDowALL: Mithra's Planetary (n. 13) 305316; LAHE, J.: Mithra kultus Kušaani riigis ja iraani usundis [The Cult of Mithra in the Kushan Empire and in Iranian Religion]. In Idakiri. Eesti Akadeemilise Orientaalseltsi Aastaraamat 2015. Tartu 2016, 89-108, here 105-108.

${ }^{50}$ CALLIERI, P.: On the Diffusion of the Mithra Images in Sasanian Iran. New Evidence from a Seal in the British Museum. East and West 40 (1990) 79-98.

${ }^{51}$ GRENET, F.: Mithra ii). Iconography in Iran and Central Asia. Encyclopaedia Iranica. http:// www.iranicaonline.org/articles/mithra-2-iconography-in-iran-and-central-asia

${ }^{52}$ See SARRE, Fr. - HERZFELd, E.: Iranische Felsreliefs. Aufnahmen und Untersuchungen von Denkmälern aus alt- und mitteliranischer Zeit. Berlin 1910, 199-200, pl. 92-93; FRYE, R. N.: Mithra in 
painting that has been destroyed. It used to decorate the ceiling of a niche for Buddha's statue in Bāmīan. The Taliban destroyed this painting already in 1999, before destroying the statues, but there have remained some photos of this painting. The painting is dated to the 6th century AD. ${ }^{53}$

4) The birth from a rock. Among the reliefs of the Roman cult of Mithras there are reliefs that represent Mithras' birth from a rock. By their frequency these images are in the second place after the images depicting him killing a bull. God's birth from a rock is a motif that has parallels in ancient Greco-Roman mythology (e.g. Attis' birth), but there are also some interesting parallels to be found in Iranian and Mesopotamian mythology. In Iranian mythology we can find an idea of heaven that consists of stones. ${ }^{54}$ Mithras' birth from a rock can be compared to the Mithras' appearance as the sun god in the sky. In Mesopotamian mythology there is described a mountain, into which the sun descends at night and from which it emerges in the morning. ${ }^{55}$ In this case, the rock could be an equivalent of that mythical mountain. There is one exciting Iranian visual parallel to images of Mithras' birth from a rock. On one of the Sassanid-era seals that is kept in the British Museum and was published in 1990 by Callieri, ${ }^{56}$ Mithra is surrounded by an intented halo. The God grows directly out of the top of a mountain that is depicted as a triangle formed by circular rocks. This image is very similar to some of the images depicting Mithra's birth from a rock during the period of Roman Empire. The seal is dated to the 4th or 5th century. $^{57}$

5) Mithras' water miracle. In several reliefs Mithras is depicted shooting an arrow into the rock from which spouts water. The closest parallel to this motif is considered to be the story of the Old Testament, where Moses struck the rock with his staff and water gushed out. ${ }^{58}$ But one should not leave unmentioned the fact that in Iranian mythology one of the special features of Mithra is his bringing out the water. Already in the Avesta Mithra occurs as a god who reigns over the water and waters those who are thirsty, and this way he is already described in the hymn that is dedicated to him, originating from the late Achaemenid era. ${ }^{59}$

6) The connection of both deities to the cosmic order. It cannot be overlooked that both the Roman Mithras and the Iranian Mithra are depicted with the cosmic symbols. ${ }^{60}$ On the Roman Mithras' coat there are stars depicted. ${ }^{61} \mathrm{He}$, like Atlas, is

\footnotetext{
Iranian Archaology. In Duchesne-Guillemin (n. 13) 205-211; StAusBerg, M.: Die Religion Zarathustras: Geschichte, Gegenwart, Rituale. Bd. 1. Stuttgart 2002, 214; GRENET (n. 51).

${ }^{53}$ GRENET (n. 51).

${ }^{54}$ MERKELBACH (n. 7) 97.

${ }^{55}$ See Bivar, A. D. H.: Mithra and Mesopotamia. In Hinnells, J. R. (ed.): Mithraic Studies. Proceedings of the First International Congress of Mithraic Studies. Manchester 1975, II 275-289.

${ }^{56}$ CALliERI (n. 50) 79-98.

${ }^{57}$ GRENET (n. 51).

${ }^{58}$ VERMASEREN: Mithras (n. 25) 69

${ }^{59}$ Yašt 10. 61.

${ }^{60}$ See about them CLAUSS (n. 7) 65-72.

${ }^{61}$ See the wallpaintings from Capua (VERMASEREN, M. J.: Mithriaca I. The Mithraeum at S. Maria Capua Vetere. Leiden 1971, pl. III) and from Marino.
} 
holding up the sky, ${ }^{62}$ or there is a globe in his hands that refers to him as a cosmocrator ${ }^{63}$ or he is surrounded with zodiac. ${ }^{64}$ There are no similar visual depictions of Mithra in Iranian cultural space, but there are descriptions that refer to him as to the preserver and holder of cosmic order ${ }^{65}$ and in this way he is described already in the earlier texts of the Avesta. ${ }^{66}$

7) Mithras' sacrifice as the creator of fertility. It has been debated a lot whether the central motif of the Roman Mithras' mythology, Mithras sacrificing a bull, can be derived from Iranian mythology. As a parallel to this there are mentioned two killings of bulls in the Bundahišn. ${ }^{67}$ The first bull is killed by the evil spirit Ahriman at the beginning of time in order to destroy the creation of god Ohrmazd. ${ }^{68}$ The second bull is killed by gods at the end of time, to mix a drink using its fat and marrow together with the holy haoma plant in order to give immortality to the people that have been resurrected from the dead. ${ }^{69}$ These parallels can be argued, since sacrificing a bull was also common in ancient religions, in addition to the fact that Mithra does not kill a bull in the Bundahišn, and finally because this text is not ancient enough to consider it to be the source of the motif of Mithras killing a bull. It is known that the Bundahišn was written in the period after Islam reached Iran, in 8th or even in 9th century AD. Despite that, however, one detail on the reliefs depicting killing of a bull by the Roman Mithras has caught the attention of scholars. This detail has exact parallel in the Bundahišn. As we know, sometimes on the reliefs of the cult of Mithras there are depicted ears of grain or clusters of grapes near to the wounds on the throat of the dying bull or a sheaf growing out of bull's tail. In the Bundahišn it is described how, from the body of the bull which was killed by Ahriman, 55 kinds of grain and 12 different kinds of medicinal plants sprouted. ${ }^{70}$

Thus the killing committed by the evil spirit was turned into good deed, due to the fact that people got new, useful plants. Because of chronological reasons we cannot say that the motif could be borrowed from the Bundahišn, but it is remarkable that the idea of a sacrifice that creates plants is important in the mythology of IndoBarberini.

${ }^{62}$ So on the Neuenheim relief (CIMRM II, Fig. 337 - Mon. 1283) and on the fresco in the Palazzo

${ }^{63}$ See CIMRM II, Fig. 101 - Mon. 354.

${ }^{64}$ See CIMRM II, Fig. 218 - Mon. 810; Fig. 226 - Mon. 860; Fig. 237 - Mon 985.

${ }^{65}$ See TURCAN, R.: The Cults of the Roman Empire. Trans. by A. Nevill. Oxford 1996, 223.

${ }^{66}$ Yašt 10. 116. See also LAHE, J. - KALDA, M.: Mitra kuju Indias ja Mithra kuju iraani usundites - uurimus võrdlevast mütoloogiast [Mitra in India and Mithra in Iranian Religions: A Study on Comparative Mythology]. Mäetagused 65 (2016) 117-160.

${ }^{67}$ The name, meaning "Primal creation," traditionally given to a major Pahlavi work of compilation, mainly a detailed cosmogony and cosmography based on the Zoroastrian scriptures but also containing a short history of the legendary Kayanids and Ērānšahr in their days (see MACKENZIE, NEIL D.: "Bundahišn". Encyclopaedia Iranica. http://www.iranicaonline.org/articles/bundahisn-primal-creation. See LAHE, J.: Mithra ja Mithras: küsimus Iraani ja Väike-Aasia Mithra kultuse ning Rooma Mithrase kultuse omavahelistest seostest ja Rooma Mithrase kultuse päritolust [Mithra and Mithras: the Question of the Relationship between the Cult of Mithra in Iran and Asia Minor and the Cult of Mithras of Rome and the Origins of the Roman Cult of Mithras]. Usuteaduslik Ajakiri 68.1 (2015) 122-151, here 133-136.

\footnotetext{
${ }^{68}$ Bundahišn 4.

${ }^{69}$ Bundahišn 34.

${ }^{70}$ Bundahišn, 6 E 1 . See also MerkelBACH (n. 7) 12-13.
} 
Iranian nations, but not important in Greco-Roman mythology. Already in the Avesta, however, Mithra is the giver of fertility (in the widest sense of the word), as he gives many successive oxen and spacious pastures to his worshippers. ${ }^{71}$

8) Mithras' military attributes. Finally, it should also be mentioned that sometimes the Roman Mithras is depicted with various military attributes, such as the bow and dagger. ${ }^{72}$ The Indian Mitra lacks any kind of military features - they belong to the god Indra. ${ }^{73}$ However, the Iranian Mithra has some military characteristics: he is depicted with a sword in his hand already on the coins of Kushan Empire from the 1 st and 2 nd century. ${ }^{74}$ In the hymn in the Avesta from the pre-Christian period he is described as a fighter against contract violators and witches. ${ }^{75}$ At the same time military features are not dominant in the case of the Iranian Mithra and the Roman Mithras.

\section{THE INDIAN MITRA AND THE IRANIAN MITHRA}

If one compares the Mithra who is worshipped in Iranian cultural space to the Indian god Mitra, one can also notice many similarities. ${ }^{76}$ I will mention just some of the most important common features. In addition to the etymological kinship of their names, both deities are considered to rule over the cosmic order and observe that treaties and agreements are being followed. ${ }^{77}$ They are vigilant and never sleep, they are merciful and forgiving, but at the same time they are strict with violators of contract. ${ }^{78}$ Both gods have relationships with the sun and fire. ${ }^{79}$ Of course, these two deities have also many differences, but similarities that are also expressed by similar expressions, such as the fact that the god Mithra was worshipped already in the IndoIranian period, when Iranian and Indian tribes had not yet been separated from each other. $^{80}$

${ }^{71}$ Yašt 10. 28, 65. Mithra is mentioned no fewer than 170 times in the extant Avesta - 126 times in Yašt 10. He bears the famous title of vourugaoyaoiti - "having wide pastures", or grasslands - 111 times (JAfAREY, A. A.: Mithra, Lord of Lands. In HinNells, J. R. [ed.]: Mithraic Studies. Proceedings of the First International Congress of Mithraic Studies. Manchester 1975, I 54-61, here 55).

${ }_{72}^{72}$ See CIMRM II, Fig. 100 - Mon. 353; Fig. 596 - Mon. 2184; Fig. 19 - Mon. 48, 8-10.

${ }^{73}$ See LAHE-KALDA (n. 66).

${ }^{74}$ See MACDOWALL: The role (n. 13) 142-150; MACDowALL: Mithra's Planetary (n. 13) 305316; LAHE: Mithra kultus (n. 49) 105-108.

${ }^{75}$ Yašt 10, 1-2.18.

${ }^{76}$ See LAHE-KALDA (n. 66).

${ }_{77}^{7}$ GondA, J.: Mitra in India. In Hinnells, J. R. (ed.): Mithraic Studies. Proceedings of the First International Congress of Mithraic Studies. Manchester 1975, I 40-52; SCHMIDT, H.-P.: Mithra i). Mitra in old Indian and Mithra in old Iranian. Encyclopaedia Iranica. http://www.iranicaonline.org/articles/ mithra-i.

${ }^{78}$ SCHMIDT (n. 77).

${ }^{79}$ LAHE-KALDA (n. 66).

${ }^{80}$ Puhvel (n. 36) 335-355. See also Bailey (n. 36) 1-20 and Thieme: The Concept (n. 36) 21-39. 


\section{CONCLUSION}

In conclusion, it can be said that the Iranian Mithra and the Roman Mithras are definitely not the same deity (the same thing can be said about the Indian Mitra and the Iranian Mithra), but they have some common ground that includes not only the names of the gods, but also a number of characteristics and iconography. I chose deliberately for the comparison sources that are older than the Roman cult of Mithras or originated from the time the cult still existed. I believe that relating similar and very specific mythological and iconographic motifs with the deity who has the same name can be difficult to explain by just random coincidences. Therefore one can claim that one of the main prototypes for the new god of the Roman Empire, Mithras, has been also the god Mithra, who was popular in Iranian cultural space at the time when the cult of Mithras began to emerge. We do not know exactly how the founders of the cult of Mithras got to know that god, but as Greek authors refer to him in the ancient world, he was therefore known already in pre-Christian era. Keeping in mind the tight connections of the Roman Empire with the nearest and most distant territories that I mentioned in the beginning of my paper, there is nothing exceptional in the fact that Romans learned about that god. From the geographical point of view the most probable place for that to have happened was Asia Minor, but we must not forget that even this area belonged to the sphere of influence of Iranian culture. So we cannot prove that the Mithras' mysteries grew out of the Iranian religion, as was argued by Cumont and Widengren, but nevertheless similar features of those two deities allow one to talk about the contribution of Iranian (or, more broadly, Indo-Iranian) mythology to the emergence of the new god in the era of the Roman Empire.

The radical point of view that claims that the Iranian Mithra and the Roman Mithras have nothing in common, except the name, is therefore not justified.

Jaan Lahe

School of Humanities

Tallinn University

Estonia

jaan.lahe_01@tlu.ee 
